\title{
AS LIÇÕES DOS ESTUDOS SOBRE DIREITO E DESENVOLVIMENTO
}

Brian Z. Tamanaha

THE LESSONS OF LAW AND DEVELOPMENT STUDIES

TRadução Tatiane Honório Lima Revisão técnICa José Rodrigo Rodriguez REVISÃo da TRAdução Fábio Luiz Lucas Carvalho

\section{RESUMO}

A PARTIR DA LEITURA DE DUAS COLETÂNEAS DE TEXTOS SOBRE DIREITO E DESENVOLVIMENTO, QUE REÚNEM ARTIGOS PUBLICADOS DESDE A DÉCADA DE 1960, ESTE TEXTO, PUBLICADO EM 1995, AVALIA OS RESULTADOS DA PESQUISA NA ÁREA E DISCUTE SEU DIRECIONAMENTO FUTURO. OS DOIS PRINCIPAIS PARADIGMAS DESTE CAMPO, A "TEORIA DA MODERNIZAÇ̃̃o" E A "TEORIA DA DEPENDÊNCIA", SÃO EXAMINADOS E CRITICADOS EM FACE DO CONTEXTO SÓCIO-POLÍTICO E INTELECTUAL; E DA CRISE QUE DOMINOU OS ESTUDOS SOBRE DIREITO E DESENVOLVIMENTO, A partir do texto de David M. TRUBek e Marc Galanter, "Acadêmicos auto-Alienados..." DE 1974. São discutidos TAMBÉM TEXTOS DE DIREITO INTERNACIONAL QUE TRATAM DO "DIREITO AO DESENVOLVIMENTO" E A PRODUÇÃo DA ÉPOCA NO CAMPO DO DIREITO E DESENVOLVIMENTO. A PARTE FINAL DO ARTIGO MOSTRA OS RESULTADOS E AS DEFICIÊNCIAS DESTA TRADIÇÃO TEÓRICA E MOSTRA QUE A CRIAC̄̃ DA ÁREA É A MANIFESTACC̃̃ DE UMA CRISE MAIS GERAL, RESULTANTE DE UMA PERDA NA CRENÇA NAS CIÊNCIAS SOCIAIS RESULTANTE DO PÓS-MODERNISMO.

PALAVRAS-CHAVE

DIREITO; DESENVOLVIMENTO; MODERNIZAÇÃO; DEPENDÊNCIA; PÓS-MODERNISMO

\section{ABSTRACT}

THIS ARTICLE, PUBLISHED IN 1995, EXAMINES AND CRITICIZES THE RESULTS OF LAW \& DEVELOPMENT RESEARCH SINCE THE 60'S, BASED UPON TWO COLLECTIONS OF TEXTS PUBLISHED IN THE 90'S. IT PRESENTS AND SHOWS THE SHORTCOMINGS OF THE TWO MOST IMPORTANT THEORETICAL PARADIGMS IN THE CHAMP, THE MODERNIZATION THEORY AND THE DEPENDENCY THEORY, AND EXAMINES THE NATURE OF THE CRISIS THAT DOMINATED THE L\&D STUDIES SINCE THE PUBLICATION OF THE 1974 ARTICLE "ACADEMICS IN SELFESTRANGEMENT..." BY DAVID M. TRUBEK AND MARC GALANTER. IT ARGUES THAT THE CRISIS THAT DOMINATED THE CHAMP IS A MANIFESTATION OF A BROADER CRISIS THAT RESULTS FROM THE HEGEMONY OF POST-MODERN THOUGHT AND ITS LACK OF CONFIDENCE ON SOCIAL SCIENCES HEURISTIC POWER. THE ARTICLE ALSO EXAMINES INTERNATIONAL LAW TEXTS ON THE "RIGHT TO DEVELOPMENT" AND THE THEN RECENT PRODUCTION ON L\&D.

\section{KEYWORDS}

LAW, DEVELOPMENT, MODERNIZATION, DEPENDENCY, POSTMODERNISM.

\footnotetext{
relação entre direito e desenvolvimento tem sido um campo de estudo acadêmico por cerca de trinta anos. A recente publicação de duas compilações 1 de artigos sobre o tema oferece a oportunidade de rever os avanços alcançados pela área, bem como seu estado atual e futuro direcionamento no contexto da resenha de dois livros.
} 
Law and Development*, editado por Anthony Carty, traz artigos do início da década de 1970 e final da década de 1980. A primeira parte do livro refere-se aos dois principais paradigmas que dominaram a área - teoria da modernização e teoria da dependência; a segunda parte reproduz o debate, na direita, pelo desenvolvimento; e a parte final lida com o tema de direito internacional e desenvolvimento. Essa coletânea, amplamente representativa, contém diversos artigos influentes sobre a temática de Direito e desenvolvimento e fornece, ainda, uma consistente introdução com vistas ao progresso desse campo de estudo.

Editado por Sammy Adelman e Abdul Paliwala, Law and Crisis in the Third World $^{* *}$ é composto de artigos recentes dos principais estudiosos sobre Direito e desenvolvimento, os quais lidam com uma gama de assuntos atuais, partindo da teoria jurídica até chegar ao constitucionalismo, ao direito penal, à litigância resultante de movimentos sociais (social action litigation), ao comércio internacional, à crise da dívida e a vários aspectos concernentes à relação mulher e Direito em países em desenvolvimento.

Juntas, essas obras oferecem um rápido e sofisticado acesso ao florescente campo da literatura. ${ }^{1}$ Uma revisão dessa área é oportuna, uma vez que os estudos sobre direito e desenvolvimento têm existido por tempo suficiente para progredirem em direção à maturidade. Não obstante, tal campo de estudo tem sido caracterizado por um aspecto extraordinariamente peculiar: a persistência com a qual seus participantes têm-se declarado estar "em crise". Tal estado foi anunciado pela primeira vez em 1974 em um artigo de autoria de David Trubek e Marc Galanter, intitulado "Acadêmicos auto-alienados: reflexões sobre a crise norte-americana da disciplina direito e desenvolvimento". ${ }^{2}$ Quase vinte anos depois, Adelman e Paliwala declararam que a crise persiste. ${ }^{3}$ Inúmeras questões são suscitadas por esse estado de crise que aparentemente aflige a área, as mais importantes sendo: (1) qual é a natureza da crise? (2) Há alguma solução?

Proponho rever essa área de conhecimento a fim de sugerir os principais ensinamentos que ela produziu. Muitas dessas lições estão implícitas no material. Elas se relacionam não apenas ao papel que o Direito desempenha em países em desenvolvimento, mas também à natureza e ao efeito do estudo do Direito nestes. Para tanto, procederei da seguinte forma: primeiramente, farei um esboço das teorias da modernização e da dependência. Minha intenção é ir além da habitual e perene discussão acerca dessas teorias para colocá-las em um contexto sócio-político-intelectual mais amplo. Demonstrarei de que forma essas teorias se relacionam e influenciam a literatura acerca do campo direito e desenvolvimento. Em seguida, discutirei a tensão debilitante que transpassa o campo, os ensinamentos que acredito que devam ser aprendidos e, ainda, discorrerei a respeito da suposta crise. 


\section{TeOria dA MODERnizAÇÃo}

\section{I Movimento De Desenvolvimento político}

A teoria da modernização, paradigma que primeiro instruiu o movimento de desenvolvimento político, surgiu em consequência da $2^{a}$ Guerra Mundial, originalmente por meio dos esforços de economistas americanos, cientistas políticos e sociólogos. ${ }^{4}$ Suas bases teóricas deviam fortemente ao funcionalismo estrutural de Parsons. Em sua forma mais simples, essa teoria defendia que o desenvolvimento era um inevitável e evolucionário processo de crescimento de diferenciação social, o qual produziria, em ultima instância, instituições econômicas, políticas e sociais semelhantes àquelas no ocidente. O resultado de tal processo seria a criação de um sistema de mercado livre, de instituições políticas democrático-liberais e do chamado império do direito (rule of law). ${ }^{5}$

De acordo com essa teoria, eram essenciais quatro elementos para que houvesse o desenvolvimento político. ${ }^{6}$ O primeiro, racionalização, baseava-se nas conhecidas dicotomias encontradas nas teorias sociais de Durkheim, Weber, Tonnies e Parsons, envolvendo mudanças do particular ao universal, da atribuição à realização e da afetividade à neutralidade afetiva - todas supostamente acompanhando a diferenciação funcional de sociedade. O segundo elemento consistia numa ênfase na integração nacional ou construção da nação, especialmente importante em virtude dos diversos conflitos étnicos que ameaçavam os países em desenvolvimento. O terceiro elemento referia-se à democratização, a qual enfatizava o pluralismo, a competitividade e a responsabilização (accountability). Por fim, o último elemento dizia respeito à mobilização ou participação a ser alcançada, em especial, pela educação, com o objetivo de expandir a proporção de populares oriundos de extratos sociais mais baixos ativamente envolvidos na disputa política.

A autoconfiança e a convicção no progresso que caracterizavam os teóricos da modernização na década de 1950 e início da de 1960 tinham sucumbido a um profundo pessimismo no fim da década de 1960, pessimismo esse induzido pelo fracasso dos países em desenvolvimento em progredir economicamente como previsto e, ainda, pela desintegração de instituições políticas e pela proliferação de regimes militares autoritários, desvirtuando, portanto, as hipóteses da teoria a respeito do desenvolvimento político. Assim, a realidade demonstrava-se obstinadamente resistente à teoria.

A reação inicial foi enxergar o fracasso como consequência de problemas internos dos países em desenvolvimento. O diagnóstico predominante era de que tais países careciam de atitudes adequadas, isto é, a cultura "política” ou "cívica” adequada, necessárias à manutenção bem-sucedida de instituições ocidentais. Essas atitudes consistiam em uma série de orientações direcionadas à comunidade nacional, à legitimidade do governo, à democracia, à obediência às leis do Estado, à função e às 
obrigações dos atores políticos e burocráticos e, por fim, à responsabilidade dos cidadãos em relação ao sistema político. ${ }^{7}$

Contudo, rapidamente, a própria teoria da modernização foi submetida a um intenso e crítico exame minucioso. Provou ser alvo fácil às investidas do etnocentrismo, do evolucionismo, do raciocínio teleológico inválido e da ingenuidade. Além disso, o paradigma funcionalista estrutural que fundamenta a teoria da modernização foi alvo de crescente ataque, especialmente pelo fato de que era uma teoria social conservadora orientada à preservação de um status quo injusto, disfarçado em uma ciência neutra. ${ }^{8}$

Uma eminente crítica interna foi defendida pelo cientista político Samuel Huntington, o qual argumentava ser um equívoco equiparar modernização e desenvolvimento político. ${ }^{9}$ Huntington notou ainda que muitos aspectos referentes à modernização - urbanização, progressivo letramento, industrialização e difusão dos meios de comunicação de massa - coincidiram com um lento desenvolvimento político nos países em desenvolvimento, ou mesmo com a deterioração de instituições políticas. Os preceitos surpreendentemente autoritários desse teórico visavam favorecer a construção de instituições políticas, em especial um partido político hegemônico que pudesse exercer um controle substancial em detrimento da participação. $\mathrm{O}$ estabelecimento da ordem deveria ser o objetivo primordial, e Huntington não tinha nenhum escrúpulo em incitar a ideia de que "o apoio americano deveria se dirigir ao mais forte dos partidos cujos objetivos fossem compatíveis com os nossos". ${ }^{10}$ A partir desses preceitos, a Realpolitik havia invadido a academia.

A teoria da modernização e o movimento de desenvolvimento político influenciado por aquela "perderam as forças no início da década de 1970". ${ }^{11}$ Antes de migrar para uma discussão específica a respeito da relação direito e desenvolvimento, visto que se relaciona com a teoria da modernização, um aspecto raramente mencionado deve ser enfatizado. Muitos dos eventos supradescritos devem ser compreendidos no contexto do movimento de direitos civis e dos protestos contrários à Guerra do Vietnã que haviam cindido a sociedade americana no fim da década de 1960 e início da década seguinte, numa proporção inédita desde a Guerra Civil. Acadêmicos foram profundamente afetados, porquanto os campi universitários foram terreno para alguns dos mais intensos conflitos. A desordem induziu, para alguns, uma nova ênfase aos valores da ordem e, para muitos, a um questionamento do sistema americano e de seus ideais.

O movimento de desenvolvimento político começou a lograr êxito no período de otimismo que sucedeu o triunfo do bem sobre o mal na $2^{\text {a }}$ Guerra Mundial, e entrou em colapso quando da perda da inocência que caracterizava os Estados Unidos no final da década de 1960. Por conseguinte, o fim da teoria da modernização não foi ocasionado única ou talvez mesmo fundamentalmente pelo seu malogro em ter se originado fora dos países em desenvolvimento. Muitos teóricos desenvolvimentistas estavam bem cientes de que a teoria da modernização era um modelo que 
consistia em uma série de ideais que poderiam ser alcançados unicamente por meio de um grande esforço em longo prazo. Tal teoria estava condenada pelo fato de que, segundo vários estudiosos aflitos, esses ideais por si só não mais pareciam autoexplicativos ou dignos de exportação.

\subsection{O movimento direito e desenvolvimento}

O movimento direito e desenvolvimento entrou em curso, de fato, somente a partir da metade da década de 1960, ${ }^{12}$ quando o declínio deste já havia sido iniciado. ${ }^{13} \mathrm{~A}$ maior parte das levas iniciais de artigos sobre esse tema foi publicada no decênio 1965-1975, ${ }^{14}$ coincidindo diretamente com as mudanças na sociedade americana. Consequentemente, pelas mesmas razões que levaram o movimento de desenvolvimento político à queda, o movimento direito e desenvolvimento estava fadado ao fracasso, a despeito da situação do Direito em países em desenvolvimento. Embora eu pretenda estabelecer isso brevemente com mais detalhes, um simples fato fornece um apoio inicial: Trubek e Galanter anunciaram o fim do movimento direito e desenvolvimento em 1974 - menos de dez anos depois de começar a ser levado a sério. Contudo, dez anos é tempo suficiente para avaliar o sucesso ou fracasso do que era universalmente reconhecido ser um projeto de dificuldade monumental.

O movimento direito e desenvolvimento adotou os princípios básicos da teoria da modernização, aderindo à noção de que o progresso evolucionário resultaria, em última instância, em ideais e instituições jurídicas semelhantes àqueles vistos no ocidente. Conforme descrito por Galanter no artigo "The Modernization of Law", publicado 1966: "progressos na Europa e em qualquer outro lugar devem ser vistos como fases em uma transformação mundial para sistemas jurídicos desse tipo 'moderno'. Essa espécie de modernização perdura, atualmente, tanto nos novos Estados quanto nos antigos". ${ }^{15}$

Um primoroso debate teórico acerca da função que o Direito desempenha em questões de desenvolvimento foi incluído no artigo "Toward a Social Theory of Law: An Essay on the Study of Law and Development”, de Trubek, reproduzido na compilação de Carty. ${ }^{16}$ Em teoria, o direito é essencial ao desenvolvimento econômico, porquanto fornece elementos necessários ao funcionamento de um sistema de mercado. Esses elementos incluem leis universais uniformemente aplicadas, as quais geram previsibilidade e permitem planejamento; um regime de lei contratual que assegure expectativas futuras; e lei de propriedade para proteger os frutos do trabalho. Na teoria, o Direito auxilia o desenvolvimento político servindo de espinha dorsal ao estado liberal democrático. Além disso, é o meio pelo qual o governo atinge seus objetivos e, ainda, serve para restringir ações governamentais opressivas ou arbitrárias.

Trubek e Galanter detalharam as características centrais do modelo de império do direito liberal, como se segue: 
1) A sociedade é composta de indivíduos que anuem ao Estado pelo seu próprio bem-estar;

2) O Estado exercita controle sobre os indivíduos por meio da lei e é, ao mesmo tempo, limitado por esta;

3) As leis são destinadas a alcançar propósitos sociais e não oferecem vantagem especial a nenhum indivíduo ou grupos dentro da sociedade;

4) As leis são aplicadas igualmente a todos os cidadãos;

5) Os tribunais são as principais instituições jurídicas responsáveis por definir e aplicar a lei;

6) O julgamento é baseado em um amplo corpo de regras e doutrinas oficiais, e decisões judiciais não estão sujeitas à influência externa;

7) Os atores legais obedecem às restrições da lei, sendo que a maioria da população as internalizou, e, onde há violações às leis, a coação irá garantir a conformidade. ${ }^{17}$

Valendo-se implicitamente desse modelo, intelectuais da área judiciária americana foram aos países em desenvolvimento dispostos a agir. O foco destes, consistente com a visão de Direito como meio de engenharia social, foi a reforma da educação e da profissão jurídicas nesses países como instrumento de alcance de objetivos de desenvolvimento.

Assim como ocorrera no movimento de desenvolvimento político com relação à teoria da modernização, em sua obra "Acadêmicos auto-alienados...", Trubek e Galanter criticam o modelo judiciário liberal por ser "etnocêntrico e ingênuo". 18 Esses autores identificaram duas maneiras pelas quais o modelo era etnocêntrico. Primeiramente, contrastava nitidamente com a realidade dos países em desenvolvimento. Em vez de pluralismo político, havia estratificação social, diferenças de classes acentuadas e governos autoritários. O Estado era fraco em comparação a um clã ou a uma vila. A grande maioria da população não havia internalizado as normas jurídicas. Frequentemente as leis eram promulgadas para atender aos interesses da elite econômica. E os tribunais eram tipicamente fracos ou irrelevantes. Em segundo lugar, Trubek e Galanter argumentavam que era potencialmente danoso exportar uma visão instrumental do Direito. Quando o Estado é cooptado por grupos autoritários, o Direito, visto em termos fundamentalmente instrumentais, não pode servir de mecanismo controlador. Desprovido de seus próprios valores internos e 
objetivos, se torna um instrumento daqueles que controlam e estabelecem as metas do Estado.

Trubek e Galanter não ofereceram, contudo, nenhuma sugestão acerca do que deveria substituir o modelo ocidental. Em vez disso, propuseram uma abordagem puramente negativa, uma "crítica eclética”, na qual os elementos do paradigma jurídico liberal eram "tratados como inerentemente problemáticos". ${ }^{19}$ Pouco tempo depois da publicação do artigo desses dois teóricos, o movimento direito e desenvolvimento nos Estados Unidos quase expirou: o dinheiro parou de circular nos fundos, vários institutos e programas voltados ao assunto regrediram ou terminaram e os intelectuais voltaram-se a outras questões.

Esses eventos ocorridos na academia jurídica norte-americana, no entanto, não significaram o fim da teoria direito e desenvolvimento. Focando em antigas colônias, estudiosos franceses e ingleses, em especial, juntamente com um determinado número de acadêmicos africanos, latino-americanos e indianos, continuaram a pesquisar e a escrever a respeito do tema, desenvolvendo um rico conjunto de material. Mais significante, advogados (nativos e expatriados), em países em desenvolvimento, continuaram, a passos acelerados, a apropriar-se de leis e a construir instituições jurídicas baseadas nos modelos do ocidente. As Nações Unidas e seus vários mecanismos também foram envolvidos no trabalho de desenvolvimento jurídico, participando desde o delineamento de modelos de contratos até a promoção de códigos de conduta com vistas a proteger os interesses dos países em desenvolvimento. Sinais da crescente "globalização do Direito" eram agora visíveis; nesse processo, países em desenvolvimento foram incluídos em regimes jurídicos mundiais, como o GATT $^{20}$ e o direito dos mares, e a homogeneidade estava crescendo nas leis nacionais internas em áreas como direito contratual, direito comercial, e até mesmo no direito constitucional. ${ }^{21}$

A crise entre teóricos da área de direito e desenvolvimento não se infiltrou nas classificações daqueles engajados na prática jurídica em países em desenvolvimento - os primeiros se defrontando com tarefas concretas e essenciais a serem resolvidas. Eles não poderiam ser indulgentes para com a magnificência da crítica eclética. Desse modo, a realidade e a necessidade do desenvolvimento jurídico permaneciam incólumes em relação à paralisia na teoria do desenvolvimento.

Apesar disso, a obra "Acadêmicos auto-alienados...", de Trubek e Galanter, permanece, indubitavelmente, como a única de maior influência nos estudos sobre o tema em questão, conforme foi evidenciado pelo fato discutido nas introduções de ambas as coletâneas aqui resenhadas. Um sinal marcante desse domínio contínuo e uma indicação de fracasso em progredir é a seguinte declaração de Adelman e Paliwala imediatamente abaixo do cabeçalho "Pauta para o Futuro": "o fio que liga as contribuições a esse volume é a crítica do Direito liberal e da teoria do desenvolvimento e a relevância dessa crítica à vida das pessoas nos países em desenvolvimento" (p.22; 
grifo do autor). Essa pauta para o futuro é apenas mais do mesmo. A crítica por si só, sem um esforço igual ou maior de construção positiva, apenas deixa um legado de destruição. Consequentemente, é imprescindível libertar-se da coação de pensamento na área imposta pelo raciocínio refletido em "Acadêmicos auto-alienados...".

\section{I.3 AUTO-ALIENAÇÃo É NACIONAL E PERTENCE À PÁTRIA}

Não há melhor maneira de colocar os eventos em perspectiva do que pensar na passagem do tempo. Trubek, depois da coautoria em artigo consideravelmente bemsucedido, começou a se tornar figura central no movimento crítico de estudos jurídicos (Critical Legal Studies - CLS). ${ }^{22}$ "Acadêmicos auto-alienados...", embora tivesse sido publicado antes mesmo do nascimento "oficial" do movimento, foi peça fundamental na erudição do CLS, por meio de seu ataque ao liberalismo jurídico e dedicação ao método crítico.

Essa ligação íntima com o CLS é significante por dois motivos. Primeiramente, não há dúvidas de que os primeiros estudiosos eram profundamente influenciados pelos protestos antiguerras e de direitos civis da década de 1960 e início da década seguinte. Assim, o CLS foi um movimento nascido exclusivamente a partir das experiências americanas. Em segundo lugar, mesmo no auge de sua proeminência, o CLS não se estendeu para além do círculo de acadêmicos esquerdistas das faculdades de Direito dos Estados Unidos; era um fenômeno de poucas conexões evidentes com a realidade da prática jurídica.

Inquestionavelmente, a tradição liberal do império do direito (rule of law) requer constantes lembretes acerca das formas nas quais malogra em corresponder às suas várias reivindicações exageradas. O CLS prestou-se à valiosa função de manter a crítica viva em uma tradição jurídica demasiadamente segura de si. Não obstante, é crucial ter em mente que essa iniciativa crítica coexistiu simbioticamente com as já robustas tradições do império de direito predominantes no ocidente.

Independentemente da relação com o CLS, o fato de "Acadêmicos auto-alienados..." estar muito mais relacionado com eventos internos do que com a situação nos países em desenvolvimento pode ter sido conclusivamente estabelecido pelo próprio artigo. Dessa forma, Trubek e Galanter listaram apenas quatro fontes para o desafio ao liberalismo jurídico: (1) "conhecimento empírico do terceiro mundo"; (2) "perda da crença no legalismo liberal como retrato da sociedade norte-americana"; (3) "incertezas acerca da universalidade da experiência americana ou desejo por ela"; (4) e "descrença em relação aos motivos políticos (tanto do governo dos Estados Unidos quanto daqueles do Terceiro Mundo)". ${ }^{23}$ Três dessas quatro fontes foram original ou exclusivamente relacionadas a eventos ocorridos nos Estados Unidos.

Apenas a primeira fonte citada, referente ao vácuo entre o modelo e a realidade, foi inteiramente baseada na situação existente nos países em desenvolvimento. Mas mesmo essa primeira fonte foi basicamente ligada à desordem política vivenciada nos 
Estados Unidos. Trubek e Galanter admitiram que "o pensamento legalista liberal sobre desenvolvimento sempre reconheceu que haveria lacunas entre o modelo e a realidade jurídica no terceiro mundo. De fato, o propósito do modelo era precisamente permitir ao reformista situar essas lacunas e traçar projetos para preenchê-las" (grifo do autor). ${ }^{24}$ Particularmente sobre esse aspecto há uma investigação de um exemplo primordial citada por Trubek e Galanter para adesão continuada ao liberalismo jurídico: ${ }^{25}$ o artigo "The New Development: Can American Law and Legal Institutions Help Developing Countries?”, escrito por Thomas Franck em 1972 e reeditado na coleção Carty (p. 3-37). Franck engajou-se em uma longa discussão sobre as limitações da relevância do modelo americano (p. 18-24). O autor concluiu que apenas aspectos selecionados desse modelo eram transferíveis e, mesmo assim, somente com o máximo de prudência. Dessa forma, até mesmo os supostos pecadores estavam bem cientes dos problemas identificados por Trubek e Galanter.

Depois de reconhecer que a discrepância entre o modelo e a realidade empírica nos países em desenvolvimento já era largamente percebida, Trubek e Galanter começaram a admitir que o problema real era a recém-despertada consciência "do vácuo entre o modelo de Direito na sociedade e as realidades jurídicas dos Estados Unidos propriamente dito. ${ }^{26}$ Portanto, no final, todas as razões citadas por esses autores, para desafiar o modelo jurídico liberal, estavam ligadas a eventos "domésticos".

A ironia em tal situação é patente: Trubek e Galanter atacaram teóricos do direito e desenvolvimento pela exportação etnocêntrica destes do modelo liberal de império do direito, embora eles tivessem feito a mesma coisa - transmitiram aos países em desenvolvimento uma atitude e metodologia críticas geradas por uma crise interna nos Estados Unidos em relação ao império do direito. A crítica eclética pode ser essencial ao funcionamento adequado dos sistemas de império do direito já estabelecidos no ocidente. As questões são, contudo, completamente distintas quando essa mesma técnica negativa e implacável é aplicada em países que ainda têm de estabelecer o império do direito.

Um argumento final contra o ponto de vista expresso em "Acadêmicos auto-alienados...” é o de que enquanto Trubek e Galanter tinham razão em alertar sobre os perigos de instigar uma visão instrumental do Direito em países em desenvolvimento, esses teóricos fracassaram em acrescentar que essa visão instrumental também era francamente questionada nos Estados Unidos (pelos conservadores), porquanto eram vistas como depreciação do império do direito. Na verdade, Roberto Unger, principal filósofo do movimento CLS, afirmou que a ascensão de uma visão instrumental do Direito era aspecto central da desintegração do império do direito e da mudança para uma sociedade pós-liberal e um estado de bem-estar social. ${ }^{27}$

Eu poderia sugerir que, em uma notável contradição, a implicação da objeção de Trubek e Galanter a respeito das atitudes instrumentais acerca do Direito está em conflito direto com o ímpeto do argumento e o legado de tais teóricos ao campo de 
estudo em questão: o que é necessário em um país em desenvolvimento - para proteger-se contra os perigos de uma visão meramente instrumental do Direito - é um sistema estabelecido e operante de império do direito, orientado de maneira formalista! O instrumentalismo funciona melhor quando inserido como um aspecto do Direito, não como a essência do império do direito. Na ausência de forças sociais vigorosas para fiscalizar o estado, e a menos que alguma outra solução antes não engendrada seja delineada, apenas o respeito ao império do direito pode efetivamente conter governantes autoritários.

A análise comparativa de Yash Ghai acerca das constituições liberal e socialista na África (em ADELMAN; PALIWALA, p. 51-75) fornece apoio adicional para esse argumento. Ghai demonstrou que a diferença essencial entre essas duas formas é que as constituições liberais retratam o Direito enquanto autônomo e imparcial, orientado a proteger os indivíduos do governo; ao passo que as constituições socialistas veem o veem em termos meramente instrumentais, como forma de induzir uma sociedade socialista e alcançar os objetivos do partido predominante. Ghai sustenta que a fachada neutra das constituições liberais frequentemente mascara e permite a manifestação de desigualdades sociais e econômicas existentes, mas que, apesar disso, a ideologia do império do direito não está totalmente desprovida de efeito positivo.

Por conta do poder próprio dessa ideologia, o declarado comportamento inconsistente em relação a esta - por parte dos governantes ou dos governados é passível de ser posto em dúvida. Desse modo, a ideologia age para restringir os excessos oficias e assegurar, em certa medida, os direitos e as liberdades dos cidadãos (Id., p. 55-56).

Uma das principais fontes de opressão e ganância em países em desenvolvimento atualmente diz respeito aos governos autoritários. A premissa central do sistema liberal de estado do direito é a proteção dos indivíduos da tirania do governo. Teóricos da área de direito e desenvolvimento devem empenhar-se em delinear maneiras pelas quais o modelo de império do direito possa ser adaptado às circunstâncias locais e incentivado a amadurecer, em vez de despender a maior parte de seus esforços desmantelando o modelo.

Embora fosse instrutivo, o paradigma jurídico liberal elucidado por Trubek e Galanter era seriamente capcioso, na medida em que insinuava que todos os elementos descritos eram pré-requisito ao sistema de império do direito. Mesmo os Estados Unidos, como observado pelos teóricos, não satisfaziam a descrição. Muitas variações do império do direito atuam ao redor do mundo nos dias atuais, coexistindo com culturas tanto de cunho individualista quanto com as de teor comunitário. Ademais, tal paradigma sempre consistiu mais em uma série de ideais do que um conjunto específico ou necessário de acordos institucionais. 
Uma descrição minimalista do império do direito exigiria apenas que o governo aceitasse e executasse as leis promulgadas pela autoridade política competente e tratasse seus cidadãos com o mínimo de dignidade, e que, além disso, haveria acesso a um judiciário, ou outras instâncias responsáveis pela tomada de decisões, de caráter justo e neutro (até o alcance possível) para atender às reivindicações ou resolver disputas. Esses elementos básicos são compatíveis com muitos acordos socioculturais e, não obstante os conflitos em potencial, tais elementos têm muito a oferecer aos países em desenvolvimento.

\section{I.4 UMA PAUTA PARA O FUTURO}

Terminarei esta parte contrastando brevemente dois ensaios presentes na coletânea de Adelman e Paliwala - "Law's Infamy", de Peter Fitzpatrick (p. 27-50) e "Third Generation Rights and Social Action Litigation", de Jill Cottrell (p. 102-126).

O ensaio de Fitzpatrick é uma exposição provocante acerca da natureza mítica do Direito. O teórico foca principalmente o Iluminismo, defendendo, de maneira convincente, que o Direito tem sido envolvido em imagens de progresso e ordem ao ser contrastado com uma imagem inventada de selvageria. De acordo com o autor, o Direito é virtualmente irredimível, e conclui que "o displicente amparo do Direito na causa do desenvolvimento é invalidado em seu próprio princípio” (p.27).

Esse ensaio, contudo, discorre muito pouco acerca da relação direito e desenvolvimento ou sobre os países em desenvolvimento, e é implacavelmente negativo, enfatizando os diversos acontecimentos terríveis que têm ocorrido em nome do Direito, mas, por outro lado, não mencionando nada a respeito do benefício oriundo desse "mito". Sem oferecer alternativas, a explanação de Fitzpatrick são de falta de perspectiva, crise e autoestranhamento. É o exemplo perfeito do "pessimismo autoindulgente que tem caracterizado a teoria e a prática do direito no desenvolvimento". ${ }^{28}$

Mais do que qualquer outra coisa, o campo de direito e desenvolvimento precisa de explanações nítidas acerca dos usos positivos do Direito. O ensaio de Cottrell é uma descrição pormenorizada da postura ativa de certos julgamentos na Corte Suprema indiana no tocante a litígios de interesse público (PIL). Essa corte agiu de forma eficaz em questões como impedir prolongadas detenções pré-julgamentos de suspeitos (em muitos casos, tais detenções ocorriam por muito mais tempo do que o máximo possível em punições), reforçar leis de proteção ambiental e investigar a detenção de crianças menores de dezesseis anos. Em cada uma dessas instâncias, a Corte logrou certo sucesso, apesar da recalcitrância ou assídua oposição por parte do Estado. Cottrel identifica os vários problemas relacionados ao tratamento dos casos de PIL pela Corte, incluindo o fato de que nem todos os juízes indianos se interessavam por eles. Ademais, a autora aponta ainda razões pelas quais tal prática possa vir a não funcionar em outros países em desenvolvimento. Entretanto, conclui que tais casos servem de modelos a serem seguidos em outras jurisdições. 
Outros tipos valiosos de explanações são as descrições instrutivas de Bruce Zagaris (em Carty, p. 121-165) sobre as ciladas e poderes de um programa sólido de desenvolvimento do Direito no Caribe, bem como o artigo de Paul e Dias (em Carty, p. 303-330) concernentes aos exemplos da abordagem "ascendente", às técnicas de desenvolvimento que enfatizam a organização da população pobre das regiões rurais para formar associações e reunir seus bens com vistas a um bem comum, e o uso do Direito para combater as ações do Estado ou estimular o governo a agir. ${ }^{29}$

A reunião de mais exemplos similares auxiliará a imaginação, de forma pontual, a projetar variações ou soluções análogas em outros contextos. ${ }^{30}$ Depois de muitas décadas de trabalho devotado de pessoas em países em desenvolvimento, o resultado final poderá ser a realização de mudanças nativas bem-sucedidas do império do direito ao redor do mundo, mantendo seus elementos centrais mesmo alterando-os para se adaptarem às circunstâncias locais. Essa mensagem de esperança estipula uma agenda para o futuro.

\section{TEORIA DA DEPENDÊNCIA}

\section{I Precedentes}

A teoria da dependência, de inspiração marxista, preencheu o vácuo deixado pelo colapso da teoria da modernização em meados da década de 1970. Essa teoria foi elaborada no mundo em desenvolvimento, fundamentalmente por estudiosos latinoamericanos. Em oposição à teoria da modernização, a qual enfocava exclusivamente fatores internos aos países em desenvolvimento enquanto causas do fracasso para o desenvolvimento, a teoria da dependência defendia que as origens do subdesenvolvimento poderiam ser encontradas na história e na estrutura do sistema capitalista.

Colonizadores exploraram os recursos naturais e o trabalho das áreas colonizadas, venderam seus produtos a estas, restringiram as colônias de competir com produtos produzidos pelos países colonizadores e, além disso, estabeleceram e protegeram corporações, plantações e encraves de colonizadores brancos em colônias, frequentemente acompanhados de licenciamento exclusivo, direitos de comércio e regimes jurídicos das colônias. ${ }^{31}$

O fim da colonização não pôs fim a esse sistema de exploração. Países em desenvolvimento foram incorporados ao sistema de mercado mundial em evidente desvantagem; esses países careciam de uma base industrial estabelecida e de uma tecnologia atualizada de transporte e infraestruturas de comunicação. Desenvolver os aspectos necessários envolvia a atração de investidores estrangeiros, a obtenção de empréstimos financeiros do ocidente e a aquisição de equipamentos industriais e tecnologia ocidentais. Muito do desenvolvimento consequente voltou-se à criação de bens mais para exportação ao ocidente do que para o consumo doméstico. Essa política 
econômica deixou os países em desenvolvimento com bases produtivas pouco diversificadas, sujeitas aos caprichos dos consumidores no ocidente, vulneráveis às barreiras comerciais estabelecidas por Estados ocidentais, a fim de proteger seus produtores domésticos, e dependente da saúde geral das economias ocidentais. Em suma, a imagem projetada pela teoria da dependência era a de um centro ocidental e uma periferia em desenvolvimento, em que a riqueza do primeiro é baseada na manutenção da última em um estado de permanente dependência e subdesenvolvimento. ${ }^{32}$

A teoria da dependência alegava que, nos países em desenvolvimento, as elites locais formavam alianças de classe com capitalistas estrangeiros e, frequentemente, com funcionários públicos locais, os quais, por sua vez, apoiavam os interesses da elite. As vítimas desse processo global eran as massas de população rural pobre e os moradores de bairros urbanos carentes nos países em desenvolvimento, os quais compartilhavam dos poucos benefícios do desenvolvimento que ocorre.

Há um inegável poder na visão da teoria da dependência, que integrava um conjunto de fenômenos políticos, econômicos e sociais discrepantes e fornecia uma explanação abrangente e singular, a qual deu origem a um nacionalismo econômico agressivo em uma série de países em desenvolvimento, notavelmente na América Latina e na Índia, ${ }^{33}$ gerando políticas que enfatizavam a substituição de importação associada a medidas protecionistas voltadas à indústria local.

O ensaio de Joseph Jova "Private Investment in Latin America: Renegotiating the Bargain” (escrito com C. Smith e T. Crigler, p. 333-362), presente na coletânea Carty, fornece uma descrição detalhada dos esforços da América Latina para lidar com alguns dos problemas identificados pela teoria da dependência. Esses esforços incluíam a aplicação de restrições à repatriação dos lucros de investidores estrangeiros, a pressão pelo despojamento do controle majoritário por certo período em favor da posse por nacionais, a imposição de limites de preços para compra de tecnologia, e a exigência de que disputas sobre compensação por expropriação de bens estrangeiros fossem examinadas em cortes internas. Os resultados foram díspares. Os negócios indicavam prontidão para se adaptar às restrições, mas nos países de pior sorte essas medidas resultaram na redução do investimento estrangeiro (p. 360).

A despeito do poder explanatório e dos muitos convertidos à teoria da dependência, a realidade demonstrava-se obstinadamente resistente, como o fez com a teoria da modernização. Há uma ampla evidência de que o desenvolvimento industrial genuíno ocorreu e continua a ocorrer em países em desenvolvimento - muito mais do que a teoria da dependência imaginava ser possível. "Na verdade, as estatísticas estão facilmente à mão para mostrar que a vitalidade do crescimento econômico em grande parte do terceiro mundo é substancialmente maior do que no norte."34

O Relatório de Investimento Mundial de 1994 apontou que, em anos recentes, o investimento estrangeiro 'flui nos países em desenvolvimento em crescimento contínuo' ao mesmo tempo em que o investimento nos países desenvolvidos passava por 
uma recessão. ${ }^{35}$ Também é aparente que uma mudança fundamental está ocorrendo na distribuição global da produção, como refletido em manifestações crescentes de angústia no ocidente acerca da vantagem competitiva injusta dos baixos custos de mão-de-obra em países em desenvolvimento, bem como sobre a transferência acelerada de trabalhos não qualificados a países em desenvolvimento. Além disso, como a populosa China tem demonstrado repetidas vezes nos últimos anos o poder de barganha, vinculado ao fato de o país ser um grande consumidor de mercado em potencial, que não deve ser subestimado.

Outro problema para a teoria da dependência era a insuficiência de sua estrutura marxista, a qual designava a dinâmica do capitalismo e das classes como fatores explicativos exclusivos. O impacto difuso de rivalidades religiosas, nacionais, étnicas e de clãs, dentro e através dos países em desenvolvimento, não poderia ser simplesmente explicado pela teoria da dependência. Ademais, tornava-se cada vez mais óbvio que a ampla disparidade entre os países em desenvolvimento no âmbito do crescimento poderia ser explicada apenas por fatores internos a cada país - precisamente como a teoria da modernização havia argumentado -, diferenças essas, por exemplo, no tocante a recursos naturais, níveis de educação, orientações culturais acerca do trabalho e da poupança, da cultura política e da natureza, e da história das instituições políticas e econômicas.

Deve ser ressalvado que esses problemas que a realidade apresentava à teoria da dependência eram consistentes com os princípios da teoria da modernização. Como observado, "poderia aparentar, mesmo em retrospecto, que os escritos da dependência representavam apenas a perspectiva limitada e de curto prazo, enquanto a abordagem [da modernização] comprovava-se melhor capacitada para explicar o curso de mudança no terceiro mundo por um tempo relativamente longo". ${ }^{36}$

Especulações à parte, o prestígio da teoria da dependência padeceu claramente. Atualmente, os modelos mais proeminentes para o desenvolvimento são os recémindustrializados países da Ásia e sua industrialização voltada às exportações. O modelo japonês "incorporado" de (1) cooperação estreita entre governo e indústria; e (2) pregação das virtudes do livre comércio internacional, enquanto secretamente mantinham-se as barreiras às importações, atraiu um interesse considerável dos países em desenvolvimento. Além disso, em vez de democracias liberais no estilo ocidental, estes, países mais bem-sucedidos, são de facto estados de um só partido, caracterizados por um autoritarismo brando. ${ }^{37}$ Abordagens atuais combinam aspectos tanto da teoria da modernização quanto da teoria da dependência, rejeitando, ao mesmo tempo, aspectos de ambas.

Enquanto isso, os dois dogmas predominantes do Banco Mundial e do Fundo Monetário Internacional, sacralizados como condições vinculadas à provisão de empréstimos a países desenvolvidos, eram: (1) o inevitável e severo programa de ajuste estrutural, que envolvia a abertura da economia nacional às forças do merca- 
do internacional, permitindo às moedas serem livremente convertidas (resultando em desvalorização), eliminando subsídios para a indústria local e forçando a privatização de empresas estatais; e (2) a "boa governança" - isto é, impedir o governo de interferir no mercado, mantendo um orçamento balanceado e desenvolvendo uma democracia multipartidária, bem como o império do direito. ${ }^{38}$ Como essas medidas de caráter exclusivamente interno revelam, a teoria da dependência detém pouca influência sobre essa massa controlada pelo ocidente.

2.2 TEORIA DA DEPENDÊNCIA E O DIREITO: DIREITO INTERNACIONAL DE DESENVOLVIMENTO Os teóricos da dependência, na verdade, "prestaram pouca atenção ao Direito", 39 pois - condizentes com a visão marxista do direito como mera superestrutura à base econômica - acreditavam que "as formas e as ideias legais são secundárias e basicamente derivativas". ${ }^{40}$ As discussões jurídicas dedicadas à teoria da dependência geralmente focavam medidas aprovadas por países em desenvolvimento para melhorar a situação, ou como o Direito servia de instrumento à expansão colonial ocidental. ${ }^{41}$

A teoria da dependência, contudo, serviu de inspiração para o chamado Direito Internacional de Desenvolvimento. Quase três quartos da coletânea Carty lida com o assunto, o que inclui o direito ao desenvolvimento, refletindo, assim, a atenção desproporcional que recebeu na literatura. Em essência, o Direito Internacional de Desenvolvimento envolve um esforço para assegurar aos países em desenvolvimento tratamento preferencial e direito de posse referente ao auxílio de desenvolvimento, geralmente relacionado a preferências de comércio, alívio de débito, empréstimos com juros baixos ou concessões totais, bem como transferência de tecnologia a baixo custo. Promover o direito ao desenvolvimento como um direito humano fundamental é a parte mais ambiciosa de tal projeto.

Quase desconhecido há vinte anos, o Direito Internacional de Desenvolvimento veio à tona no final da década de 1970 por meio de uma série de relatórios, resoluções, declarações e conferências patrocinadas pelas Nações Unidas, clamando pela criação de uma "Nova Ordem Econômica Internacional", para corrigir as iniquidades estruturais no sistema econômico mundial, as quais foram atribuídas, sobretudo, às consequências da colonização. ${ }^{42}$ Daí a conexão com a teoria da dependência, embora esta seja raramente invocada de forma direta na literatura.

Apenas o direito ao desenvolvimento será tratado aqui. Na maioria dos casos, o Direito Internacional de Desenvolvimento compreende os mesmos assuntos e utiliza a mesma análise, mas recusa-se a afirmar que um “direito” está envolvido. Carty compilou um conjunto de artigos consideravelmente contrastantes sobre o tema - o pró, apresentado por Roland Rich em "O Direito ao Desenvolvimento enquanto um Direito Humano Emergente" (p. 223-264), e o contra, por Jack Donnelly em "Em busca do Unicórnio: A Jurisprudência e as Políticas do Direito ao Desenvolvimento” (p. 169-205). 
De acordo com Rich, as fontes do direito ao desenvolvimento incluem a "metamorfose do Direito Internacional de um direito de coexistência para um direito de cooperação", o reconhecimento de que os poderes coloniais devem uma restituição a suas antigas colônias, o reconhecimento de que o subdesenvolvimento "foi um subproduto do desenvolvimento dos países do Oeste"; além dos conceitos morais comuns de equidade e justiça (p. 225-231). Rich admite, contudo, que o Direito Internacional é fundamentalmente baseado na anuência. Assim, o autor prosseguiu a relatar detalhadamente todas as evidências imagináveis para essa anuência, apontando para as diversas declarações e resoluções das Nações Unidas e seus meios no sentido de que aos países em desenvolvimento é devido tratamento preferencial, bem como às várias práticas de estado que proporcionavam esse tratamento, desde a concessão de auxílio ao desenvolvimento às preferências comerciais para os países em desenvolvimento autorizados pelo GATT (p. 231-250).

A evidência fornecida por Rich e outros é, na melhor das hipóteses, uma tentativa. Nenhuma das resoluções ou declarações citadas possui efeito legal, e há um caráter incômodo em relação ao argumento de prática do estado, o qual se utiliza do fato de que os países do ocidente concederam auxílio ao desenvolvimento e preferências no passado (com os estados beneficentes afirmando assiduamente que agiam dessa forma sem boa vontade, não por obrigação legal [Carty, p. 424, nota 73]), para defender que o tratamento era compulsório.

Talvez o aspecto mais estranho e problemático do caso apresentado por Rich envolva a identificação do sujeito em favor do qual o Direito se estabelece. A alegação de que o direito ao desenvolvimento é um direito coletivo, associado ao fato de que os estados são os sujeitos principais do Direito Internacional, quase impelem à conclusão de que o direito é conferido ao Estado, embora também se tenha identificado como um direito dos indivíduos e das "gentes" (CARTY, p. 190-197). O argumento é estranho porque a sugestão de que o Estado é "um beneficiário em seu próprio direito de legislação dos direitos humanos" (CARTY, p. 251) é um oximoro e ofende a origem e a história dos direitos humanos como proteção contra o Estado. Além disso, há pouca atratividade em sustentar que os governos do terceiro mundo, muitos dos quais possuem terríveis registros de violação aos direitos humanos e cobiças fiscais por ganhos privados, devam ser autorizados pelo direito a se beneficiar do ocidente.

Não há necessidade de repetir o argumento mordaz de Donnelly contra o direito ao desenvolvimento. Considerando o fracasso de tal direito disposto a resultar em qualquer coisa além de uma proliferação de livros e artigos sobre o assunto, de autoria de estudiosos do Direito Internacional, a crítica filosófica desse autor está quase destruída. O direito logo não será mais reconhecido.

Isso não significa dizer que a discussão acadêmica do direito, a qual mostra sinais de afilamento a partir de seu auge na metade da década de 1980, tornava-se inútil. Não há dúvidas de que usufruía de um valor simbólico na comunidade da área de 
Direito Internacional, e tenha, talvez, facilitado a aceitação dos casos mais modestos apresentados em outras áreas do Direito Internacional de Desenvolvimento. Há razões otimistas para se acreditar que ramos focados mais na proteção dos interesses dos países em desenvolvimento do que na imposição de obrigações afirmativas no ocidente obterão certo sucesso. Esses esforços variam desde tentativas de assegurarlhes uma parte da "herança comum da humanidade", em assuntos que vão da exploração do mar às atividades no espaço, ${ }^{43}$ até a adoção de códigos de conduta para corporações transnacionais e transferência de tecnologia que levem em conta sua situação especial. ${ }^{44}$

Contudo, um caráter utópico permeia a discussão do Direito Internacional de Desenvolvimento. Apesar de a situação poder mudar, a realidade do Direito Internacional - incorporada no princípio de anuência - tem sido, em grande medida, política, doméstica e global, como, ditada pelos interesses próprios de nações-Estado e seus governantes.

O problema potencialmente catastrófico que aparece de forma funesta sobre todo o restante, confrontando os países em desenvolvimento atualmente é a pesada crise da dívida. Esta é tema favorito na literatura sobre direito e desenvolvimento e é discutida em ambas as coletâneas aqui resenhadas. O pagamento da dívida resulta em uma enorme transferência de riqueza dos países em desenvolvimento para os desenvolvidos. De acordo com uma fonte, essa transferência em rede atingiu 200 bilhões de dólares entre 1982 e $1987 .{ }^{45}$ Esse grande ônus é excessivo para ser superado pelos primeiros. A solução uniformemente sugerida na literatura de direito e desenvolvimento é o cancelamento da dívida em larga escala. Essa é uma atitude meramente política, a qual será, basicamente, fundada naquilo que é entendido como sendo o melhor para o sistema bancário ocidental. Como Adelman e Espiritu apontaram, "o Direito tem sido utilizado a fim de lidar com a crise, e assim aparenta ser epifenomenal.

\subsection{Trabalhando Dentro da lei}

Colocando de lado os méritos e deméritos específicos da teoria da dependência, não há como negar que os países em desenvolvimento padecem com severas desvantagens no atual sistema econômico mundial. Infelizmente, no que tange à análise jurídica, o próprio Direito é incapaz de gerar quaisquer soluções, embora possa servir como meio essencial para incorporar e auxiliar a implementação das criadas e decidas por outros; na verdade, algumas das mais óbvias e possíveis aos problemas mencionados anteriormente são extrajudiciais - por exemplo, a organização de um cartel, por devedores de países em desenvolvimento, que ameace paralisar o pagamento en masse a menos que haja um perdão significativo da dívida; ou a recusa conjunta de pagar royalties sobre temas como tecnologia, fármacos e livros, que diversos países em desenvolvimento possuem a capacidade de copiar e produzir por iniciativa própria (alguns já o fazem), exceto se esses itens forem fornecidos a custos mais baixos. 
Sugerir essas políticas não significa endossá-las. Antes, a questão é que todos os esforços para lidar com a situação por meio do Direito, interno ou internacional, por meio daqueles próprios atos, pressupõem e reforçam sua eficácia e legitimidade. $\mathrm{O}$ próprio Direito Internacional é, em grande parte, uma extensão dos princípios da tradição liberal do império do direito para a arena internacional. A noção de Direitos Humanos, por sua vez, é completamente liberal. Embora a tentativa de obter reconhecimento dos Direitos Humanos coletivos tome um rumo decididamente não liberal, isso não precisa ser interpretado como rejeição da tradição liberal; pode, em vez disso, ser considerado como uma construção e uma modificação da tradição, utilizando-se dos ideais que esta incorpora, exatamente como ocorreu na evolução dos sistemas jurídicos do ocidente. ${ }^{46} \mathrm{O}$ debate perpetuamente irresoluto entre igualdade substancial e formal demonstra que o conceito de igualdade no cerne do liberalismo pode fortalecer as reivindicações por uma distribuição mais equitativa da riqueza.

Se o Direito Internacional de Desenvolvimento reúne muitos êxitos ou não, sua própria existência representa um momento decisivo no desenvolvimento do Direito. Ao longo de muitos séculos, a história do desenvolvimento jurídico foi caracterizada pela difusão das leis ocidentais e instituições legais através da imposição colonial ou mesmo empréstimo voluntário. Muito frequentemente, ele tem sido cinicamente usado como um instrumento opressor pelos poderes coloniais ou por seus interesses comerciais; de modo crescente, estudiosos de países em desenvolvimento e outros simpáticos à sua causa tentam responsabilizar o ocidente por alguns dos ideais jurídicos que apoiou ao longo dos anos. Essas reviravoltas revelam, mais uma vez que, apesar de o império do direito ter sido manchado de sangue pelos muitos pecados cometidos em seu nome, os ideais que ele representa resistem e possuem uma vida própria.

\section{Autodestruição e o fardo do etnocentrismo}

O fim do paradigma da modernização foi sucedido pela adoção de seus opostos ideológicos. Em termos gerais, isso levou a (1) culpar o imperialismo do ocidente por todos os males dos países em desenvolvimento; (2) defender o socialismo em detrimento do liberalismo; (3) e defender que as culturas dos países em desenvolvimento devam ser protegidas contra a invasão dos valores ocidentais, em especial preservando os costumes ou modos de vida locais do alcance expansivo das leis de estado. Dentre muitos estudiosos focados em direito e países em desenvolvimento, isso resultou em uma atitude de "lei de estado ruim" ou "lei popular boa". ${ }^{47}$

Essa reação, contudo, especificamente o fato de a responsabilidade do etnocentrismo ter sido a clava usada (inicialmente por acadêmicos ocidentais) para abater praticamente tudo que fosse oriundo do ocidente - disseminou as sementes de uma tensão autodestrutiva que produziria amargos frutos em longo prazo. Essa tensão é, em parte, evidente no atrito entre os itens 2 e 3 supracitados: o socialismo é um produto 
tanto do ocidente como do liberalismo, e muitos movimentos comunistas nos países em desenvolvimento têm explicitamente se oposto aos "meios tradicionais", especialmente no que tange ao apoio a condições igualitárias para as mulheres. Para estabelecer ainda mais essa tensão e suas implicações, irei contrastar brevemente dois assuntos - um ainda não discutido em nenhuma das compilações, mas notavelmente proeminente.

$\mathrm{O}$ assunto que não foi discutido diretamente por nenhum dos colaboradores das compilações refere-se às violações dos Direitos Humanos nos países em desenvolvimento, as quais surgem em dois contextos: ações governamentais e práticas culturais. Os governos do terceiro mundo acusados desse tipo de violação têm respondido regularmente que as necessidades de construção da nação e rápido desenvolvimento justificam (temporariamente) a prevalência de outros interesses sobre a observância dos Direitos Humanos, ${ }^{48}$ e, além disso, que os Direitos Humanos são noções etnocêntricas do ocidente. Certas práticas culturais repugnantes, dentre elas os famigerados sistemas de castas e a amputação do clitóris, são defendidas integralmente como forma de preservação da cultura, ${ }^{49}$ e os Direito Humanos transgredidos são rotulados como sendo meras noções ocidentais etnocêntricas.

Os Direitos Humanos são amplamente apoiados por estudiosos do direito e desenvolvimento, mas aqueles são indubitavelmente de origem e conteúdo ocidental e liberal. Os acadêmicos que rejeitaram o império do direito liberal e os valores que representava, e que incumbiram às gerações anteriores de teóricos a exportação etnocêntrica de ideais culturais do ocidente, são incapazes de ajustar uma refutação consistente às justificas de violação dos Direitos Humanos por parte dos governos de terceiro mundo.

O tema proeminente refere-se às mulheres em países em desenvolvimento. Quatro dos doze artigos da compilação de Adelman e Paliwala lidam com a questão feminina, refletindo um aumento marcante na recorrência desse tema na literatura de direito e desenvolvimento e comparando o perfil acentuado dos assuntos de direito da mulher no ocidente. Adelman considerou o impacto das Zonas de Processamento de Exportações (EPZs) sobre as mulheres; Ann Stewart tratou a aplicabilidade do feminismo ocidental às mulheres nos países em desenvolvimento; Anne Hellum examinou o impacto da lei de Estado em mulheres sem filhos por meio do contraste do regime de direitos consuetudinários; e Paliwala discutiu a relação entre o fim dos sistemas de família ampliada e as disposições da lei de Estado em relação à custodia de filhos e auxílio financeiro a mulheres em casos de divórcio.

Essa questão apresenta um dilema para os teóricos do direito e desenvolvimento que desejam proteger culturas nativas de regimes de lei de Estado transplantados, pois para as mulheres em muitos dos países em desenvolvimento, como posto sucintamente por uma escritora, "a lei popular é a culpada". ${ }^{50}$ Muitas culturas tradicionais, como as ocidentais, favorecem os homens em detrimento das mulheres, às vezes a um extremo intragável. 
Tanto Hellum quanto Paliwala chegaram basicamente à mesma conclusão, quase a contragosto, de que as mulheres estariam em melhor situação com as leis de Estado ocidentais de teor individualista sobre estabelecimento de propriedade, pagamentos de auxílio e custódia de filhos, mesmo se fossem contra o costume. A maioria dos problemas das mulheres foi produzida mais por mudanças na sociedade - em especial pelos elos debilitantes da família ampliada - do que causada pelo Direito. O que este fez foi fornecer alternativas urgentemente necessárias às mulheres.

Um lembrete que precisa ser feito é o de que as leis que Hellum e Paliwala endossaram são exatamente as mesmas transplantadas do ocidente e aquelas instituições jurídicas censuradas no ataque ao liberalismo jurídico. Tal situação é ímpar, visto que os analistas tiveram a chance de apoiar o resultado que a lei de Estado dispôs, não obstante se entrava em conflito com modos costumeiros. Mesmo a gratidão de mulheres nativas pelo Direito não poderia fazê-lo sequer menos ocidental em sua origem e natureza, ou mesmo menos liberal.

A tensão a que me referi anteriormente pode agora ser elaborada. Os estudiosos da área de direito e desenvolvimento que condenaram a exportação de valores ocidentais, leis e instituições jurídicas estavam condenando muito daquilo que prezavam. Qualquer tentativa posterior de argumentar em favor desses valores coloca-os exatamente na mesma situação daqueles “exportadores” que eles outrora condenaram.

Adelman tropeçou nesse problema em sua defesa do Código Internacional do Trabalho para proteger os trabalhadores nas EPZs. Muitos países em desenvolvimento opuseram-se ao Código por um motivo razoável: os critérios que este impunha serem uma forma de protecionismo que enfraqueceria a única vantagem que os países em desenvolvimento têm de reduzir os custos de mão-de-obra. Mesmo líderes trabalhistas do ocidente defenderam abertamente que requerer dos países em desenvolvimento a adoção do Código é interesse econômico dos países desenvolvidos e de seus trabalhadores. ${ }^{51}$ Mas Adelman descarta a oposição dos países em desenvolvimento sem responder a ela em seu mérito, dizendo: "alguns dos mais cínicos regimes argumentam, como vimos, que o Código Internacional do Trabalho é prejudicial a seus valores sociais, políticos e culturais" (ADELMAN; PALIWALA, p. 210).

Por mais que tentem, é impossível aos teóricos do direito e desenvolvimento explicarem por que o paradigma jurídico liberal é etnocêntrico, ao passo que os Direitos Humanos, as leis transplantadas apoiando os interesses das mulheres e o Código de proteção aos trabalhadores, de esboço ocidental, não o são. Os problemas não terminam por aqui. O próximo grande tema aparente no horizonte - o meioambiente - resultará no mesmo ônus de o ocidente impor seus valores e preocupações em diminuir a velocidade do progresso dos países em desenvolvimento.

O Etnocentrismo é um fardo facilmente aplainável, difícil de defender e maleável o suficiente para apoiar quase qualquer reivindicação. Em vez de favorecer um apelo para a cessão do uso dessa poderosa arma retórica, finalizarei esta seção argumentando que 
duas percepções pós-modernas centrais irão enfraquecê-la em última instância: (1) inevitavelmente, nós enxergamos as coisas a partir de nossa própria perspectiva (formada por paradigmas étnicos, culturais, de classe, profissionais, científicos, marxistas, liberais e outras comunidades interpretativas); (2) e não há critérios ou fundamentos máximos dos quais se possa determinar a superioridade de uma concepção baseada em uma perspectiva sobre outra.

O teórico social Zygmunt Bauman descreveu as implicações da pós-modernidade na seguinte passagem:

A visão de mundo pós-moderna acarreta a dissipação da objetividade.

O elemento mais visivelmente ausente é uma referência ao terreno supracomunal e extraterritorial da verdade e do sentido. Em vez disso, a perspectiva pós-moderna revela o mundo como sendo composto por um número indefinido de agências geradoras de significado, todas relativamente autossustentadas e autônomas, todas sujeitas às suas respectivas lógicas e munidas de seus próprios recursos de validação da verdade. A relativa superioridade destas pode ser exclusivamente debatida de um modo pragmático e abertamente autorreferencial, sem reivindicação feita à autoridade supracomunal. ${ }^{52}$

O fardo do etnocentrismo - o qual, de fato, diz que "isso é de sua perspectiva, a qual não tem autoridade nenhuma em relação à minha" - é o precursor antropológico das duas percepções pós-modernas, bem como a versão popular destas.

Sempre que indivíduos se engajam em discursos sobre qualquer tema fora da área de sua própria comunidade interpretativa, inevitavelmente, eles se tornam etnocêntricos. Essa é a condição humana. Sob tais circunstâncias, acusar alguém de etnocentrismo é meramente reafirmar (em termos polêmicos) as condições epistemológicas de todo discurso voltado para o mundo exterior. Quando o reconhecimento da inevitabilidade dessas condições é amplamente disseminado e internalizado, o fardo do etnocentrismo tornar-se-á redundante. Podemos, então, voltar à discussão sobre quais ideais e visões de mundo devem ser adotados, sabendo que carecem de fundamentos básicos e estando cientes de que as únicas fontes de apoio serão encontradas em suas consequências na vida real. Até que esse dia chegue, contudo, muitos teóricos da área de direito e desenvolvimento serão prisioneiros de uma tensão autodestrutiva de criação própria destes.

\section{As lições dos eStudos De DiReito E DESENVOLVIMENTO}

Eu sugeriria que, depois de trinta anos de estudos sobre direito e desenvolvimento, aprendemos, pelo menos, as oito lições a seguir: 
- A modernização é necessária, mas não suficiente, para o desenvolvimento econômico. Isso é verdade porque o sistema de mercado mundial bem estabelecido está gradualmente resultando em uma homogeneização global de leis comerciais. Para tomar parte nesse sistema, é preciso um mínimo de infraestrutura composta por essas leis e pelas instituições necessárias para reforçá-las. Países ou grupos isolacionistas podem seguir seu próprio caminho, mas por sua conta e risco. Contudo, mesmo com um mínimo de infraestrutura jurídica no local, o ritmo e a natureza do desenvolvimento econômico serão determinados por uma miríade de outros fatores.

- A aparência de que um império do direito existe é proveitosa, mas não suficiente, para o desenvolvimento político. Ao redor do mundo, muitos dos principais elementos da ideologia do império do direito têm se tornado importantes meios de legitimação simbólica para o aparato político estatal. Yash Ghai indicou que nas gerações recentes, mesmo as constituições comunistas começaram a enfatizar "a importância da legalidade e dos direitos dos cidadãos” (em Adelman e Paliwala, p. 58). De forma semelhante, mesmo com sua conhecida forma semiautoritária, o império do direito também é regularmente adotado como aspecto integral do modelo Asiático. ${ }^{53} \mathrm{De}$ que tamanho a distância entre a aparência e a realidade possa vir a ser, antes que o sistema político padeça depende das circunstâncias de cada localidade, embora as evidências sugiram que a distância possa ser, de fato, bem grande.

- Além de tais mínimos, o Direito não é de importância primordial. O centro de gravidade em cada sociedade baseia-se numa mistura de suas peculiaridades históricas, culturais, econômicas, políticas e materiais (população, recursos naturais, tecnologia de base, entre outros). O reconhecimento da natureza derivativa e da influência secundária do Direito é um refrão virtualmente unânime de todos os lados do debate. ${ }^{54}$ Isso não nega que o Direto desempenhe sua própria e significante função como estrutura institucional e simbólica dentro da sociedade - apenas que algumas poucas soluções aos problemas serão geradas a partir do próprio Direito. Sistemas jurídicos são recursos do poder institucionalizado que se prestam a muitos usos. E, para grande desgosto daqueles que desejam reformar a sociedade por meio do Direito, na maioria dos sistemas jurídicos ao redor do mundo os juristas são técnicos que executam decisões elaboradas por outros.

- A teoria da dependência estava parcialmente certa e parcialmente errada; a teoria da modernização estava equivocada em parte, e ainda é muito cedo para dizer se estava parcialmente certa; contudo, o império do direito é compativel com ambas. A teoria da dependência diagnosticou corretamente que as aflições econômicas dos países em desenvolvimento estavam diretamente relacionadas ao legado do colonialismo e à posição desfavorável no sistema de mercado mundial; mas, por outro lado, subestimou claramente os efeitos 
potencialmente benéficos desse sistema e enganou-se ao negar a importância de fatores internos. A teoria da modernização errou ao ignorar o efeito do sistema mundial e, provavelmente, também incorreu em erro a respeito da expansão de instituições políticas democráticas e liberais - o autoritarismo brando é um rival firmemente entrincheirado. Mas, se essa teoria, em última instância, está certa - a respeito da trajetória do desenvolvimento -, isso é algo que não será conhecido até que várias gerações tenham passado. O império do direito pode lidar com ambas as teorias, ou com uma combinação das duas, ou, ainda, com a maioria das teorias econômicas e com os variados acordos políticos. ${ }^{55}$

- Países em desenvolvimento irão se beneficiar - isto é, a qualidade de vida de seus cidadãos irá melhorar -, se desenvolverem suas próprias variantes do conteúdo mínimo do império do direito. Tendo em mente que esses objetivos sempre serão realizados imperfeitamente, esse conteúdo mínimo inclui assegurar (1) que o governo atue de acordo com as regras estabelecidas na arena política e respeite os direitos civis de seus cidadãos, (2) e que haja um corpo jurídico ao qual recorrer e que incorpore a ética de tratar todos os casos, antes do recurso, de forma neutra e justa. As realidades cotidianas contrastantes dos países desenvolvidos e em desenvolvimento demonstram que o império do direito é decisivamente importante para se adquirir quando ausente, e, quando presente, é importante ser crítico em relação a ele.

- O conteúdo mínimo do império do direito pode ser mais bem estabelecido por meio de esforços voltados ao desenvolvimento jurídico - isto é, à criação de instituiçães jurídicas e do corpo da doutrina jurídica. Somente com bases fortes e uma existência estável é que o Direito pode servir de efetiva limitação às ações governamentais, assim como juízes podem desenvolver éticas jurídicas e exercitar a independência necessárias à sua função essencial. Infelizmente, os estudos sobre Direito e desenvolvimento têm minimizado, em grande medida, a importância do trabalho da doutrina e dos princípios de criação de instituição. ${ }^{56}$

- O trabalho dos teóricos de direito e desenvolvimento sempre foi substancialmente um reflexo das questões e das preocupações ocidentais. Muitos países em desenvolvimento têm focalizado a construção do Direito ao longo desse período (ao menos quando não estavam distraídos com agitações internas), e se esforçado para lidar com os diversos problemas que resultam do choque entre as leis e as instituições transplantadas e seus arredores. Reconheciam que não haveria volta, e entraram em uma crise por suas próprias razões. Repito: foi absurdo declarar o fracasso do projeto de direito e desenvolvimento depois de passados apenas dez anos. Repetidas vezes, a literatura repercutiu preocupações, em relação ao Ocidente, da subida da orientação crítica ao Direito à recente proeminência 
dos temas femininos e ao crescente interesse pelas questões ambientais. Apesar de muito ter sido aprendido sobre Direito e países em desenvolvimento, indiscutivelmente, mais ainda tem se aprendido acerca do Direito como processo social, bem como sobre sistemas jurídicos do ocidente - e não há nada de errado com isso.

- A teoria de direito e desenvolvimento, em particular, e estudos sobre direito e desenvolvimento, em geral, podem ser vistos, em grande medida, como uma discussão acadêmica do Ocidente, no mínimo no que se refere ao presente. A explicação não é apenas a de que a maioria dos estudiosos envolvidos é oriunda do Ocidente ou trabalham em universidades ocidentais. Há uma razão mais básica, até mesmo mundana. Veja a descrição dramática de Ghai acerca da situação das universidades africanas:

O encolhimento de recursos e carência de divisas internacionais levaram a uma cobrança severa de taxas das bibliotecas. Até em um país relativamente rico como a Nigéria as bibliotecas de universidades são incapazes de manter suas assinaturas dos principais artigos sobre Direito e periódicos dos países do Commom law, incluindo a Inglaterra. Dar-es-sallam, na Tanzânia, apesar de ser uma faculdade de Direito notável, tem sido capaz de encomendar poucos livros novos ou jornais por anos; a situação nas universidades de Makerere, em Uganda, e Legeon, em Gana, não tem sido muito melhor. Há ainda uma falta aguda de papel, de modo que mesmo os materiais locais não podem ser mimeografados para distribuição aos estudantes. Textos ou livros de caso escritos nas décadas de 1960 e 1970 estão esgotados; estudantes competem por uma cópia esfarrapada na biblioteca; alunos se valem muito mais das anotações feitas durante as aulas. Em muitos casos, periódicos locais cessaram a publicação por falta de apoio financeiro, e às vezes pela falta de artigos. ${ }^{57}$

A situação que Ghai descreve é extrema, mas a falta de materiais básicos é praxe nos países em desenvolvimento. A maioria dos livros e artigos sobre direito e desenvolvimento estão claramente indisponíveis. Embora a mensagem possa, apesar disso, ser de lentamente difundida a ponto de influenciar a discussão sobre questões naqueles países, o debate imediato é ocidental.

\section{LIDANDO COM A CRISE}

A crise na teoria de direito e desenvolvimento têm sido atribuída, pelos teóricos do assunto, a um colapso tanto na teoria da modernização como na teoria de dependência, devido a uma incapacidade de ambas elucidarem a realidade adequadamente. Há um elemento de verdade nessa atribuição. Outro fator é a tensão autodestrutiva, por meio da qual acadêmicos que anteriormente acusaram os desenvolvimentistas de 
etnocentrismo se veem incapacitados de argumentar a favor de uma pauta positiva sem se exporem à mesma acusação. Mas acredito que haja dois outros fatores, talvez de maior importância, que tenham gerado a crise.

O primeiro, como enfatizei, tem relação com a crise no Ocidente, com os ideais e as instituições ocidentais. Dentre as principais perdas estão as ciências sociais, em que muitos teóricos do direito e desenvolvimento são educados. A crise na ciência foi declarada na obra de Gouldner, que se tornou clássica do dia para a noite, The Coming Crisis in Western Sociology, citada em "Acadêmicos auto-alienados...", 58 por Trubek e Galanter. Mais evidências do crescimento dessa crise podem ser encontradas no relatório "Law and Development", do International Legal Center, de 1974, escrito por alguns dos maiores acadêmicos da área, o qual afirmou: "ouve-se muito nestes dias sobre a 'crise' nas ciências sociais; em nenhum lugar a crise é mais aguda do que no campo de estudos desenvolvimentistas". ${ }^{59}$ Essa crise quase destruiu a certeza anterior de que as ciências sociais poderiam fornecer respostas concretas e objetivas a muitos problemas da vida. Com a perda dessa crença, a teoria social caiu nas garras do pós-modernismo, o que gera "um estado mental marcado, acima de tudo, por seu caráter destrutivo completamente escarnecedor, desgastante e desagregador". 60

Meu posicionamento é de que a crise na teoria de direito e desenvolvimento não é isolada, mas meramente uma manifestação dessa crise mais ampla. A atitude crítica que tanto caracteriza o pós-modernismo é a mesma que caracteriza o CLS, as teorias de direito e desenvolvimento e, de fato, muitos dos trabalhos gerados pela comunidade sociolegal ocidental. Não tenho nenhuma solução para isso - apenas uma observação extraída de minha experiência pessoal. Aqueles que atingiram a maioridade quando a crise estava em plena atividade experimentaram-na de uma maneira muito diferente. Desde o começo eles aprenderam que os ideais eram menos que perfeitos e menos que perfeitamente realizáveis, e que a ciência não possuía todas as respostas. Desse modo, não há sentimento de traição ou de perda irreparável, se os ideais são corrompidos ou se a teoria não "funciona" no mundo real. Nenhum evento levaria a uma crise - apenas sugeriria que mais trabalho precisa ser feito. Ideais são algo pelo qual devemos nos esforçar para obter, e teorias são somente ferramentas.

O segundo fator na crise da teoria de direito e desenvolvimento tem relação com dois tipos de impotência. Primeiramente, o Direito não pôde resolver por si só os diversos problemas que confrontam os países em desenvolvimento. A frustração e o desapontamento dos estudiosos da área de direito e desenvolvimento, cada vez que essa incapacidade é descoberta e anunciada sob nova forma, são quase palpáveis. Entretanto, talvez a impotência seja apropriada: recorrer ao Direito para resolver problemas essencialmente sociais e políticos é, de certo modo, uma tentativa de conjurar a pauta social na realidade insistindo que o Direito requer isso.

Em segundo lugar, todos os acadêmicos estão cercados de dúvidas quanto à relevância ou impacto de nosso trabalho. Conforme citado acima, teóricos do direito e 
212 : AS LIÇÕES DOS ESTUDOS SOBRE DIREITO E DESENVOLVIMENTO

desenvolvimento têm razões ainda maiores do que o habitual para sentir uma sensação de impotência. Talvez o único remédio para essa dúvida incômoda e incessante seja empenhar-se no trabalho concreto nos países em desenvolvimento, assim como muitos desses teóricos já o fazem.

\section{NOTAS}

* CARTY, Anthony (Ed.). Law and Development. The International library of essays in law and legal theory. New York: New York University Press, 1992 (Legal cultures, 2).

** ADELMAN, Sammy; PALIWAla, Abdul (Ed.). Law and Crisis in the Third World. London, New York: Hans Zell, 1993 (African discourse series, no. 4).

1 A única disciplina negligenciada nessas coleções é a antropologia jurídica, embora muitas de suas percepções tenham sido incorporadas aos artigos. Para um panorama da literatura sobre Direito e desenvolvimento, veja a bibliografia de TAMANAHA, Brian Z. Law and Developing Countries (F1 S9 95)

2 David Trubek \& Mark Galanter, Scholars in Self-Estrangement: Some Reflections on the Crisis In Law and Development Studies In the United States, 1974 WIS L. REV. 1062 (a partir de agora Self-Estrangement). [N. E. : Publicado em português como "Acadêmicos auto-alienados: reflexões sobre a crise norte-americana da disciplina direito e desenvolvimento", In: Revista Direito GV 3, v.3, n. 2, p. 261-304, 2007 e na coletânea TRUBEK, David M. O novo direito e desenvolvimento: presente, passado e futuro. Texto selecionados de David M. Trubek. José Rodrigo Rodriguez (org.). São Paulo: Saraiva, 2009].

3 Adelman e Paliwala, Law and Development in crisis, In: Adelman e Paliwala, p. 10.

4 Ver, por via de regra, Tony Smith, Requiem of New Agenda for Third World Studies, POLITICAL SYSTEM AND CHANGE 347 (Ikuo Kabashima e Lynn T. White III eds., 1986).

5 Para uma discussão instrutiva sobre a teoria da modernização, veja David Apter, Rethinking Development: Modernization, Dependency, And Postmodern Politics (1987).

6 Ver Samuel P. Huntington, Political Development and Political Decay, in: Political System And Change, supra nota 4, em 96.

7 Ver Gabriel A. Almond, The Intellectual History of the Civil Culture Concept, In The Civil Culture Revisited 1, esp. 26-29 (G. Almond e S. Verba eds., 1980).

8 O exemplo principal dessa crítica está em Alvin W. Gouldnetrh, The Coming Crisis Of Western Sociology (1970).

9 Huntington, supra nota 6.

10 Id. p. 138.

11 Tony Smith, supra nota 4, em 349

12 Ver John H. Merryman, Comparative Law and Social Change: On the Origns, Styb, Decline \& Revival of the Law and Development Movement, 25 Am. J. Comp. L. 457,457-58 n.4 (1977). 
13 Essa cronologia contradiz a alegação de Adelman e Paliwala de que "the crisis in law and development emerged far earlier than that in development studies as a whole” (p. 10). A afirmação dos autores está incorreta. Como Tony Smith aponta, "by around 1970 [the field of political development] had become relatively moribund." Supra nota 4, em 347.

14 Ver Elliot M. Burg, Law and Development: A Review of the Literature and a Critique of "Scholars in SelfEstrangement” 25 AM. J. COMP. L. 492, 496-98 nn.17, 18,22 (1977).

15 Ver Marc Galanter, The Modernization of law, in Modernization 156 (Myron Weiner ed., 1966).

16 David Trubek, Towards a Social Theory of law: An Essay on the Study of Law and Development, 82 YALE L.J. 1 (1972).

17 Trubek \& Galanter, supra nota 2, em 1071. Tal explicação é uma versão abreviada da versão dos autores.

18 Id. em 1080

19 Id. em 1099.

20 General Agreement on Tariffs and Trade - GATT (Acordo Geral sobre Tarifas e Comércio ou Acordo Geral sobre Pautas Aduaneiras e Comércio). N.R.

21 Ver, por via de regra, Michael J. Shapiro, The Globalization of Law, 1 IND.J . Global Legal Stud, 37, 1993.

22 Ver John H. Schlegel, Notes toward an Intimate, Opinionated, and Affectionate History of the Conference on Critical Legal Studies, 36 STAN. L. REV. 391, 1984. Embora Galanter nao tenha aderido ao CLS, o autor tornou-se um influente estudioso sócio-jurídico.

23 ”Acadêmicos auto-alienados...", nota 2, supra, em 1089. Galanther listou várias das discrepâncias em seus 196 artigos (nota 15, supra, em 156-165). Muitos dos mesmos pontos podem também ser encontrados em um artigo anterior de Lawrence M. Friedman, On Legal Development, 24 RUTGERS L. REV. 11, 1969.

24 “Acadêmicos auto-alienados...”, nota 2, supra , em 1090, (grifo do autor).

25 Idem, 1096 n. 92.

26 Idem, 1091

27 UNGLER, Roberto. Law In Modern Society, p. 192-200, 1976.

28 Adelman \& Paliwala, nota 3, supra, em 10.

29 Para uma discussão mais elaborada desses temas, ver Lawyers in The Third World: Comparative and Developmenptal Perspectives. (Dias, J.; Luckman, R.; Lynch, D. O.; Paul, J. C. N. Eds., 1981).

30 Em outro trabalho demonstrei como as leis transplantadas dos Estados Unidos e instituições jurídicas trabalharam razoavelmente bem na Micronésia, permanecendo limitadas principalmente a crimes graves e transações comerciais, não interferindo nos sistemas tradicionais efetivos do restante. Ver TAMANAHA, Brian Z. Understanding Law in Micronesia: An Interpretive Approach to Transplantated Law, 1993.

31 Uma excelente descrição dessas atividades é demonstrada na obra Law-and-Development in Light of Dependency Theory, de David Greenberg's, no volume Carty, p. 89-119.

32 Para uma explicação complete da teoria da dependência, ver Francis G. Snyder, Law and Development in the Light of Dependency Theory, 14 LAW\& SOC'Y REV. 723, 1980.

33 Adelman e Paliwala, nota 3, supra, em 5.

34 Smith, nota 4, supra, em 364. 
214 : AS LIÇÕES DOS ESTUDOS SOBRE DIREITO E DESENVOLVIMENTO

35 Unctad World Investment Report, em xix, 1994.

36 Idem. em 369.

37 Ver A. Leftwich, Governance, The State and the Politics of Development 25 DEV \&. CHANGE 363 , 377-380, 1994.

38 Ver World Bank, Managing Development: The Governance Dimension, 1991.

39 Ver Snyder, nota 31, supra, em 761. Ver também Greenberg, nota 30, supra, em 98.

40 Snyder, nota 31, supra, em 780. Ver também Yash Ghai, Law, Development and African Scholarship, 50 MOD. L. REV. 750, 771 (1987) (“They regarded law as peripheral, a mere emanation of the economic forces of society.”).

41 Ver, por via de regra, Greenberg, nota 30, supra.

42 Ver Declaration on the Establishment of a New International Economic Order, GA Res. 3201, 29 UN GAOR, 6th Spec. Sess., Supp. N. 1, em 3, UN Doc. A/9559 (1974). Ver, por via de regra, Mohammedb Edjaoui. Towards A New International Economic Order, 1979; Milan Bulajic. Principles of International Development Law: Progressive Developmoent of the Principles of International Law Relating to the New International Economic Order, 1966.

43 Ver, por exemplo, David Heywood, Deep Seabed Mining: Alternative Schemes for Protecting Developing Countries from Adverse Impacts, 12 GA. J . INT’L \& COMP. L. 173 (1982); Stephen Gorove, Utilization of the Natura Resources of the Space Environment, in Light of the Concept of Common Heritage Mankind, in Third World Attitudes Towards Inernational Law 775 (SNYDER, F. E.; SATHIRATHAI, S. Eds. 1987.

44 Ver, por exemplo,, CODES OF CONDUCT OF MULTINATIONALST:THEIR IMPACT ONTHIRD WORLD COUNTRIES (Aloysius Fonseca ed., 1984); S. K. Agrawala, Transfer of Technology to LCDs: Implications of the Proposed Code, 23 INDIAN $J$. INT'L L. 246 (1983).

45 A. G. Frank, Debt Where Credit is Due. In: SINGER, H. W.; SHARMA, S. Eds. Economic Development and World Debt 34, 1989.

46 Como afirma Jack Donnelly, no cerne do liberalismo encontra-se um conjunto de princípios adaptáveis que podem auxiliar no reconhecimento de direitos sociais e econômicos, como o direito à alimentação, à saúde e ao trabalho. Jack Donnelly, Human Rights andWester11 Liberalism, In: DENG, F. M.; AN-NA'IM, A. A. Eds. Human Rights in Africa 49, 1990. Não há motivos para que esses princípios não nos leve mais longe.

47 Ver a afirmação de Antony N. Allott. In: ALLOTT, Antony N.; WOODMAN, Gordon. Eds.. Introduction to Peoples' Law and State Law: The Bellacio Papers, 1985. Richard Seidman é uma proeminente exceção; por todo esse período, ele continuou a angariar o Direito como instrumento essencial ao desenvolvimento, indo contra as atitudes na maior parte das vezes negativas que prevaleciam sobre o Direito. Ver SEIDMAN, Richard. The State, Law, and Development, 1978.

48 Para uma repetição desses argumentos, ver J. Silk, Traditional Culture and the Prospects for Human Rights in Africa. In: human Rights in Africa, nota 45, supra, em 2290-2328.

49 Para uma discussão dos temas envolvidos, ver A.A.An-Na'im, Problems O f Universal Cultural Legitimacy for Human Rights. In: Human Rights in Africa, nota 45, supra, em 331-367; Fernando R. Tesón, International Human Rights and Cultural Relativism, 25 VA. J. INT'L L. 869 (1985); R. A. Dundes, The Unanswered Challenge of Relativism and the Consequences for Human Rights, 7 HUM. RTS. Q . 514, 1985.

50 Ver K . O. Adinkrah, Folk Law Is the Culprit:Women's "Non-Rights" in Swaziland, 30-31 J. LEGAL

PLURALISM, 223 (1990-1991).

51 Jack Sheinkman (Presidente do Amalgamado Clothing and Textile Workers' Union), The Sweatshops for Children Are Unfair all Around, INT'L HERALD TRIB., 1994, p. 4, Aug. 12 (editorial).

52 Ver BAUMAN, Zygmunt. Intimations of Postmodernity 35, 1992. 
53 Os paralelos substanciais entre esse modelo e o estado de direito também foram observados. Ver L. Theberge, Law and Economic Development, 9 J. INT'L L. \& POL'Y 231, 237, 1980.

54 Ver, por exemplo, idem, em 236-238; Franck em Carty, p. 24-26; “Acadêmicos auto-alienados...”, nota 2, supra, em 1083; Snyder, nota 31, supra, em 780; Adelman/Paliwala, em 182; idem, em 286-297.

55 Como Joseph Raz afirma, o estado de direito é ainda compatível com sistemas não democráticos. RAZT, Joseph. The Authority of Law, p. 210-229, 1979.

56 Esse exemplo foi primeiramente evidenciado em um relatório emitido pelo International Legal Center que incitava explicitamente uma rejeição da pesquisa dogmática. Ver International Legal Center, Law and Development: The Future of Law And Development Research 18, 48 (1974).

57 Yash Ghai, Law, Development and African Scholarship, 50 MOD. L. REV. 750, 775 (1987).

58 “Acadêmicos auto-alienados...", nota 2, supra , em 1069.

59 International Legal Center, nota 55, supra, em 23.

60 BAUMAN, nota 51, supra, em vii-viii.

\section{REFERÊNCIAS BIBLIOGRÁFICAS}

ADINKRAH, K.O. Folk Law Is the Culprit: Women's Non-Rights in Swaziland. Journal of Legal Pluralism and Unofficial Law. Birmingham: Foundation for the Journal of Legal Pluralism African Studies Center, v. 30-31, 1990-1991, p. 9-32. AGRAWALA, S. K. Transfer of Technology to LCDs: Implications of the Proposed Code. Indian Journal of International Law. New Delhi: The Indian Society of International Law, v. 23, 1983, p. 246-336.

ALlOTT, Antony N.; WOODMAN, Gordon R. (Eds.). People's law and state law: the Bellagio papers. Dordrecht; Cinnaminson: Foris Publications, 1985.

APTER, David Ernest. Rethinking development: modernization, dependency, and postmodern politics. Newbury Park: Sage Publications, 1987.

BAUMAN, Zygmunt. Intimations of Postmodernity. [s.l.]: Ebooks Corporation, 1992.

BEDJAOUI, Mohammed. Towards a new international economic order. Paris: Unesco ; New York: Holmes \& Meier, 1979. BULAJIC, Milan. Principles of international development law: progressive development of the principles of international law relating to the new international economic order. Dordrecht: M. Nijhoff; Belgrade: Exportpress; Hingham: Kluwer Academic Publishers, 1966.

BURG, Elliot M. Law and Development: A Review of the Literature \& a Critique of "Scholars in SelfEstrangement". The American Journal of Comparative Law. New York: American Society of Comparative Law, v. 25, n. 3, 1977, p. 492-530.

DIAS, J.; LUCKMAN, R.; Lynch, D. O.; PAUL, J. C. N. (Eds.). Lawyers in the ThirdWorld: comparative and developmental perspectives. Uppsala: Scandinavian Institute of African Studies; New York: International Center for Law in Development, 1981 (Studies of law in social change and development, 3).

FONSECA, Aloysius Joseph. Codes of conduct of multinationals: their impact of Third-World countries. Rome: Herder, 1984.

FRIEDMAN, Lawrence M. On Legal Development. Rutgers Law Review. Newark: Rutgers Law School, v. 24, n. 1, 1969, p. 11-64.

GALANTER, Marc. WEINER, Myron (Ed.). The Modernization of law. In: Modernization 156, 1966.

GHAI, Yash. Law, Development and African Scholarship. The Modern Law Review. Oxford: Blackwell Publishing, v. 50, n. 6, 1987, p. 750-776.

GOROVE, Stephen. Utilization of the Natural Resources of the Space Environment in Light of the Concept of Common Heritage Mankind. In: SNYDER, Frederick E.; SATHIRATHAI, Surakiart (Eds.). Third World attitudes toward international law: an introduction. Dordrecht; Boston : M. Nijhoff, 1987.

GOULDNER, Alvin Ward. The coming crisis of Western sociology. New York: [s.n.], 1970. 
216 : AS LIÇÕES DOS ESTUDOS SOBRE DIREITO E DESENVOLVIMENTO

GREENBERG, David. Law-and-Development in Light of Dependency Theory. CARTY, Anthony (Ed.). Law and Development. The International library of essays in law and legal theory. New York: New York University Press, 1992 (Legal cultures, 2), p. 89-119.

HEGWOOD, David. Deep Seabed Mining: Alternative Schemes for Protecting Developing Countries from Adverse Impacts. Georgia Journal of International and Comparative Law. Athens: University of Georgia School of Law, v. 12 , p. $173-192,1982$

HUNTINGTON, Samuel P. Political Development and Political Decay. World Politics. Baltimore: The Johns Hopkins University Press, v. 17, n. 3, pp. 386-430, abr. 1965.

LEFTWICH, Adrian. Governance, the State and the Politics of Development. Development and Change. Malden: Willey-Blackwell, v. 25, n. 2, 1994, p. 363-386.

MERRYMAN, John Henry. Comparative Law and Social Change: On the Origins, Style, Decline \& Revival of the Law and Development Movement. The American Journal of Comparative Law. New York: American Society of Comparative Law, v. 25, n. 3, 1977, p. 457-491.

NAIM, Abd Allah Ahmad; DENG, Francis Mading. Human rights in Africa: cross-cultural perspectives. Washington: The Brookings Institution, 1990.

RAZ, Joseph. The authority of law: essays on law and morality. Oxford: Oxford University Press, 1979. RENTELN, Alison Dundes. The Unanswered Challenge of Relativism and the Consequences for Human Rights. Human Rights Quarterly. Baltimore: The Johns Hopkins University Press, v. 7, n. 4, 1985, p. 514-540.

SCHLEGEL, John Henry. Notes toward an Intimate, Opinionated, and Affectionate History of the Conference on Critical Legal Studies. Stanford Law Review. Critical Legal Studies Symposium. Stanford: Stanford Law Review, v. 36, n. 1/2, 1984, p. 391-411.

SEIDMAN, Robert Benjamin. The state, law, and development. [s.n.t.], 1978.

SHAPIRO, Michael J. The Globalization of Law. Indiana Journal of Global Legal Studies. Bloomington: Indiana University School of Law, v. 37, n. 1, 1993, p. 37-64.

SHEINKMAN, Jack. The Sweatshops for Children Are Unfair all Around. International Herald Tribune. Editorial, p. 4, 12 ago. 1994.

SINGER, H. W.; SHARMA, Soumitra. Economic development and world debt. London: MacMillan Press, 1989. SMITH, Tony. Requiem or New Agenda for Third World Studies? World Politics. Baltimore: The Johns Hopkins University Press, v. 37, n. 4, p. 532-561, jul. 1985.

SNYDER, Francis G. Law and Development in the Light of Dependency Theory. Law \& Society Review.

Contemporary Issues in Law and Social Science. Oxford: Blackwell Publishing, v. 14, n. 3, 1980, p. 723-804.

TESÓN, Fernando R. International Human Rights and Cultural Relativism. Virginia Journal of International Law v. 25 , n. 4, 1985, p. 869-900.

TRUBEK, David M.; GALANTER, Mark. Scholars in Self-Estrangement: Some Reflections on the Crisis In Law and Development Studies In the United State. Wisconsin Law Review. Madison: University of Wisconsin Law School, p. 1062-1103, 1974.

TRUBEK, David M. Toward a Social Theory of Law: An Essay on the Study of Law and Development. The Yale Law Journal. New Haven: The Yale Law Journal Company, v. 82, n. 1, 1972, p. 1-50

TRUBEK, David M. O novo direito e desenvolvimento: presente, passado e futuro. Texto selecionados de David M.

Trubek. José Rodrigo Rodriguez (org.). São Paulo: Saraiva, 2009.

TAMANAHA, Brian Z. Understanding Law in Micronesia: An Interpretive Approach to Transplantated Law. Leiden; New York: E.J. Brill, 1993.

UNCTAD. World Investment Report 1994: Transnational Corporations, Employment and the Workplace. New York; Geneva: United Nations Publication, 1994.

WORLD BANK. Managing Development: The Governance Dimension. Washington: World Bank, 1991

UNGER, Roberto Mangabeira. Law in Modern Society: Toward a Criticism of Social Theory. New York: Free Press, 1976.

Brian Z. Tamanaha

8000 Utopia Parkway Jamaica, Nova lorque 11439

PROFESSOR DA ST. JOHN'S UNIVERSITY SCHOOL OF LAW I tamanahalastjohns.edu 